pp. $71-78$

\title{
Ewa IR
}

ORCID 0000-0003-4457-9854

Szkoła Podstawowa nr 58 im. T. Kościuszki

w Krakowie

\section{Edukacja całożyciowa jako personalny wymiar realizacji osoby ludzkiej}

\begin{abstract}
Life-long Education as a Personal Dimension of the Realization of a Human Person
The article shows that lifelong education is a personal dimension of the realization of a human person, which results from the fact that a person learns throughout his life, which is inscribed in human nature. Without lifelong education, and thus taking various actions aimed at getting to know the world and oneself, expanding one's knowledge and competences, it is impossible to become a professional teacher who is to be an authority, a role model, and a specialist in his field for a student.
\end{abstract}

Keywords: lifelong education, professional competences, teacher

Słowa kluczowe: edukacja całożyciowa, kompetencje zawodowe, nauczyciel

\section{Wstęp}

Powiedzenie: „Człowiek uczy się przez całe życie” w pełni oddaje istotę całożyciowego kształcenia. Dzieje się tak dlatego, że człowiek przez całe życie się rozwija. Mówi o tym Konfucjusz:

Gdy miałem piętnaście lat, pragnąłem się uczyć. Gdy miałem trzydzieści, umocniłem się w moim postanowieniu. Gdy miałem czterdzieści, nie miałem złudzeń. Gdy miałem pięćdziesiąt, znałem moje przeznaczenie. Gdy miałem sześćdziesiąt, rozpoznawałem prawdę we wszystkim, co słyszałem. Gdy miałem siedemdziesiąt, mogłem podążać za głosem serca bez obawy zejścia na złą drogę (Konfucjusz, 2008, s. 42).

Cytat ten wskazuje, że człowiek ciągle dąży do doskonałości, samorealizacji i w ten sposób następuje również jego kształcenie. Słusznie zauważa S. M. 
Kwiatkowski (2018, s. 75), że człowiek uczy się nie tylko w instytucjach o charakterze edukacyjnym, ale również w pracy czy też dzięki uczestnictwu w życiu społecznym i kulturalnym. Można więc powiedzieć, że uczy się stale. Co więcej, nie tylko uczy się, ale także uczy innych.

\section{Kształcenie całożyciowe}

Nie tylko jednak nabywanie nowych sprawności i umiejętności, będące wynikiem wewnętrznego przekonania, jest warunkiem rozwoju. W przekonaniu Z. Pietrasińskiego (1990, s. 173-174) najważniejszym czynnikiem rozwoju dorosłych jest podejmowanie trudnych i ważnych zadań długofalowych, mających wartość ponadosobistą. Zadania te powodują modyfikację i organizację makrostruktury czynności, a także sprawiają, że jednostka, zmuszona dorastać do nowych zadań, podlega rozwojowi.

O tych nowych zadaniach, które wymuszają kształcenie oraz rozwój edukacji dorosłych, szeroko pisze T. Aleksander (2009, s. 324-325). Podkreśla on, że głównym powodem kształcenia są zmiany tempa przemian cywilizacyjnych. Najważniejszym czynnikiem, który napędza te zmiany, jest wywołany przyczynami ekonomicznymi postęp na wielu płaszczyznach: technicznej, technologicznej, organizacyjnej. Postęp ten skutkuje zmianami w otoczeniu człowieka. Sprowadzają się one m.in. do: pojawienia się bardziej wydajnych metod pracy, nowych kategorii zawodowych, destabilizacji struktur organizacyjnych, produkcji nowych urządzeń. Wszystko to sprawia, że kształtuje się nowe społeczeństwo, nazywane społeczeństwem informacyjnym. Następuje w nim zmiana dawnych stosunków interpersonalnych i nowe uporządkowanie wartości. Zmianom tym towarzyszą przeobrażenia w stosunkach międzynarodowych (konflikty, wojny, terroryzm, kryzysy polityczne), jak również $\mathrm{w}$ środowisku naturalnym (zanieczyszczenie, katastrofy ekologiczne itp.). Wszystko to powoduje chaos, niezrozumienie otaczającego świata, lęk przed nieznanym. Właśnie dlatego niezbędna jest edukacja dorosłych, za sprawą której możliwe staje się rozwinięcie nauczycielskich kwalifikacji moralnych, społecznych oraz zawodowych na wielu poziomach. A. Carleo (2013, s. 21-22) podkreśla, że nie tylko zmiany cywilizacyjne wymuszają konieczność ustawicznego kształcenia. Współczesna szkoła nie przygotowuje swoich absolwentów do życia w sposób kompletny, a z praktyki wynika, że najbardziej efektywni pracownicy to tacy, którzy się uczą oraz rozwijają swoją wiedzę i doświadczenie. Autor ten ponadto zaznacza, że kształcenie ustawiczne może wynikać z przyczyn wewnętrznych, a więc $z$ chęci samorealizacji lub zaspokajania własnych potrzeb. W tym kontekście całożyciowe kształcenie nabiera wymiaru personalnego. 
Całożyciowe kształcenie odnosi się zatem nie tylko do podnoszenia własnych kompetencji zawodowych, ale również do innych sfer. W języku angielskim całożyciowe kształcenie określa się terminem lifelong learning. W przekonaniu Komisji Europejskiej pojęcie to oznacza „wszelkie działania edukacyjne podejmowane przez całe życie w celu poprawy poziomu wiedzy, umiejętności i kompetencji w perspektywie osobistej, obywatelskiej i społecznej i/lub w związku z zatrudnieniem" (COM, 678, 2001, s. 9). Z przytoczonej definicji wynika, że Komisja Europejska postrzega całożyciowe kształcenie w sposób bardzo szeroki, zauważając, że obejmuje ono wszelkie formy edukacji, niezależnie od wieku.

W polskiej literaturze przedmiotu całożyciowe kształcenie określa się zamiennie terminami „kształcenie ustawiczne” lub „kształcenie permanentne”. A. Marcinkiewicz (2013, s. 46-47) zwraca jednak uwagę, że ujęcie to nie jest całkowicie trafne. Całożyciowe kształcenie można nazywać kształceniem ustawicznym, ale na pewno nie permanentnym. Kształcenie całożyciowe (inaczej ustawiczne) oznacza kształcenie i wychowanie człowieka przez całe życie. To potrzeba i cecha, która charakteryzuje współczesnych ludzi i warunkuje ich zdolności. Kształcenie ustawiczne (całożyciowe) odnosi się do każdego, kto śledzi zmiany zachodzące $\mathrm{w}$ świecie i społeczeństwie, dba o wszechstronny rozwój własnej osobowości w ciągu całego życia. Obejmuje pno kształcenie permanentne, ale nie jest $z$ nim tożsame. To drugie bowiem zmierza wyłacznie do podtrzymania albo ciągłego rozwijania wiedzy oraz umiejętności zawodowych.

Całożyciowe uczenie się oznacza nie tylko dobrowolną aktywność, która podejmowana jest ze względu na zaspokojenie własnych ambicji, potrzeb, zainteresowań odnoszących się do rozwoju osobistego, lecz wiąże się również z koniecznością właściwego funkcjonowania $\mathrm{w}$ otaczającej rzeczywistości, $\mathrm{w}$ tym także w życiu zawodowym (Maniak, 2015, s. 129). Z. Wiatrowski (2005, s. 364 -360) zauważa, że kształcenie ustawiczne na gruncie polskim rozumiane jest dwojako, a mianowicie jako proces całożyciowy albo jako kształcenie pozaszkolne, charakterystyczne dla dorosłości człowieka. W tym drugim znaczeniu pod pojęciem „kształcenie ustawiczne” należy rozumieć „proces systematycznego uczenia się, następujący po zakończeniu obowiązku szkolnego lub wydłużonej edukacji stacjonarnej i trwający przez cały okres aktywności zawodowej, a często także dłużej [...]".

Kształcenie ustawiczne nazywane jest również kształceniem ciągłym. W. Okoń (2001, s. 196) twierdzi, że jest to proces ciągłego doskonalenia kwalifikacji ogólnych i zawodowych, zasada współczesnego systemu oświaty, według której kształcenie musi odbywać się przez całe życie, obejmując odnawianie, poszerzanie oraz pogłębianie wszelkich kwalifikacji. Według Okonia obecny postęp naukowo-techniczny sprawia, że wykształcenie zdobyte w systemie szkolnym po prostu staje się przestarzałe, a więc istnieje konieczność kontynuowa- 
nia kształcenia przez całe życie w takich rozmiarach i formach organizacyjnych, jakie są optymalne dla przedstawicieli danego zawodu, tzn. umożliwiają im poszerzanie kwalifikacji ogólnych i zawodowych. Koncepcja kształcenia zawodowego podważa dawny pogląd, że życie ludzkie dzieli się na trzy okresy: przygotowania do życia przez naukę szkolną, okres pracy oraz okres dojrzałego uczestnictwa w życiu społecznym. W koncepcji tej podkreśla się, że oprócz kształcenia szkolnego istnieje kształcenie poszkolne. Obejmuje ono dwa elementy, a mianowicie samokształcenie oraz kształcenie organizowane przez różne instytucje w postaci kursów, szkoleń, studiów podyplomowych itp.

Współcześnie „preferuje się model nauczyciela o rozszerzonym profilu zawodowym i jednocześnie otwartym podejściu do wykonywania zadań. Aby im sprostać, aby poradzić sobie z płynnością i zmiennością, nauczyciel musi ustawicznie się doskonalić, poddawać refleksji codzienną rzeczywistość i szukać nowych rozwiązań, by łatwiej wchodzić w to, co z jednej strony oczywiste, codzienne, zwykłe, a z drugiej - jeszcze nieznane" (Szymański, Łukasik, Nowosad (red.), 2014, s. 12).

Jednym z pierwszych autorów, który podjął tematykę ustawicznego kształcenia, był R. J. Kidd, który w 1960 r. sformułował zasady kształcenia ustawicznego na poziomie edukacji dorosłych. Przypomniał on, iż kształcenie ustawiczne od wieków było tematem znajdującym odbicie w poglądach wybitnych pedagogów i humanistów, a w XX w. nabrało szczególnego znaczenia. Stworzył bardzo interesujący pogląd dotyczący kształcenia ustawicznego, wyróżniając jego trzy wymiary: „w pionie”, „w poziomie” oraz „w głąb”. Kształcenie „w pionie”, zdaniem Kidda, dotyczy przechodzenia przez poszczególne szczeble edukacji, a więc od szkoły podstawowej po studia uniwersyteckie, kończąc na studiach podyplomowych. Zasady dostępności i drożności są gwarantem kształcenia w tym wymiarze zarówno dzieci, jak i dorosłych, i to niezależnie od takich zmiennych jak: wiek, miejsce zamieszkania, zawód czy też inne czynniki, które utrudniają proces edukacyjny. Kształcenie „w poziomie” polega na poznaniu różnych dziedzin życia, kultury oraz nauki, niezależnie od edukacji realizowanej w wymiarze pionowym. Likwidacja sztucznych barier pomiędzy dziedzinami życia oraz kultury powoduje, że możliwe jest wykorzystanie tego wymiaru przez indywidualną aktywność człowieka, jak również przez działalność pozaszkolnych instytucji o charakterze oświatowym. Kształcenie „w głąb” wiąże się Natomiast $\mathrm{z}$ jakością edukacji, a wyraża się $\mathrm{w}$ bogatej motywacji kształcenia, zainteresowaniach intelektualnych, umiejętnościach samokształceniowych, w stylu życia, który jest zgodny z ideą ustawicznego kształcenia oraz efektywnego wykorzystania czasu wolnego. R. J. Kidd ujął kształcenie ustawiczne w sposób szeroki, zaliczając do niego trzy elementy: kształcenie w szkole, poza szkołą w instytucjach oświatowych oraz samokształcenie (za: Półturzycki, 2005, s. 17). 
Podobny podział cyklu całożyciowego kształcenia przyjęła Komisja Europejska, wyróżniając kształcenie formalne, pozaformalne oraz nieformalne (COM 678, 2001, s. 9). Pierwsze odnosi się do hierarchicznego systemu instytucji oświatowych, za pomocą którego uczniowie przez certyfikaty, świadectwa oraz dyplomy selekcjonowani są do różnych ról społecznych. Kształcenie pozaformalne dotyczy tych aktywności edukacyjnych, które nie są usytuowane w ramach formalnego systemu oświaty. Można tu wyróżnić: seminaria, kursy, studia podyplomowe, koła miłośników, odczyty i różne inne formy dokształcania. Kształcenie nieformalne obejmuje natomiast te działania o charakterze edukacyjnym, w których jednostka ucząca się ma możliwość przyswajania wiedzy, umiejętności, wartości oraz postaw w trakcie własnych doświadczeń (Marcinkiewicz, 2013, s. 47).

Kształcenie ustawiczne jest niezwykle ważne w przypadku zawodu nauczyciela. Nauczyciel jest bowiem organizatorem własnej pracy, przykładem aktywności intelektualnej, a w związku $\mathrm{z}$ tym powinien znać oraz stosować różne metody nauczania i jednocześnie wypracowywać nowe rozwiązania. Potrzeba rozwoju nauczyciela wynika głównie ze specyfiki zawodu oraz jego funkcji (wychowawczej, kształcącej, opiekuńczej i kulturowej). Trzeba podkreślić, że rozwój zawodu nauczyciela wymusił zmiany w systemie doskonalenia zawodowego oraz samokształcenia nauczycieli. Celem tego systemu jest nie tylko nabycie określonej wiedzy, ale również przeobrażenie osobowości. Należy zaznaczyć, że nauczyciel oddziałuje na powierzonych mu wychowanków całą swoją osobą, a $w$ związku $z$ tym już samo przygotowanie do zawodu powinno być całościowym wspomaganiem rozwoju osobistego. Trzeba mieć jednak na uwadze fakt, że wykształcenie zdobywane w trakcie studiów o profilu pedagogicznym nie jest w stanie ująć wielości problemów, z którymi nauczyciel spotyka się w szkole. W związku $z$ tym istnieje konieczność przygotowania go do stawianych przed nim zadań. Jeśli więc studia nie przygotowują w pełni do pracy w szkole, to istnieje potrzeba samokształcenia i dalszej edukacji. Można więc powiedzieć, że istotą zawodu nauczyciela jest stałe uczenie się, w tym również samokształcenie, które odnosi się do poszukiwania nowej wiedzy oraz uzupełnienia tej, która została już nabyta. Rozwój zawodowy nauczyciela można rozpatrywać na dwóch płaszczyznach. Pierwsza z nich, mniej rozległa, wiąże się z dokształcaniem przez zdobywanie wiedzy i umiejętności w instytucjach, które są do tego powołane, druga natomiast $-\mathrm{z}$ udziałem $\mathrm{w}$ konferencjach, seminariach oraz samokształceniem. Ta druga płaszczyzna jest bardzo ważna i powinna uwzględniać nie tylko potrzeby współczesnych wychowanków, ale również potrzeby rynku pracy, zmieniający się świat i reformy systemu edukacyjnego. Samokształcenie stanowi jeden $\mathrm{z}$ najbardziej twórczych rodzajów kształcenia całożyciowego, może służyć zarówno adaptacji, jak i specjalizacji nauczycieli w miejscu pracy (Poliwka-Gorczyńska, 2013, s. 85-86). 
Właśnie w kontekście ustawicznego kształcenia W. Dróżka i J. Madalińska-Michalak (2016, s. 162) piszą o stawaniu się nauczycielem. Warto w tym miejscu przytoczyć ich słowa:

[...] proces stawania się nauczycielem, od pojawienia się motywacji do wyboru zawodu oraz jej dojrzewania, aż do pełniejszej identyfikacji z zawodem, dokonuje się przez cały okres aktywności zawodowej. W procesie tym [...] ważną rolę odgrywają doświadczenia przedzawodowe kandydatów na nauczycieli $\mathrm{z}$ dzieciństwa, domu rodzinnego, nauki szkolnej, a następnie z okresu kształcenia wstępnego.

Cytowane autorki wiążą proces ustawicznego kształcenia nauczycieli z wieloma czynnikami. Niezwykle istotne w dążeniu do mistrzostwa pedagogicznego jest nabycie odpowiedniego doświadczenia i kompetencji przed uzyskaniem kwalifikacji do wykonywania zawodu. W tym kontekście należy wspomnieć, że sam proces osiągania mistrzostwa pedagogicznego rozpoczyna się w momencie wyboru studiów, które przygotowują do uzyskania kwalifikacji zawodowych. Podczas studiów przyszły nauczyciel powinien nabyć kompetencje umożliwiające mu wykonywanie tego zawodu. Chodzi tu o kompetencje z zakresu psychologii, metodyki, dydaktyki itp., a więc wszystkich tych dziedzin, z których wiedza jest niezbędna w pracy dydaktyczno-wychowawczej. Ważne znaczenie mają także praktyki pedagogiczne, które stanowią rodzaj egzaminu predyspozycji do wykonywania zawodu. Dają one możliwość uczestniczenia w różnych sytuacjach edukacyjnych $\mathrm{w}$ środowisku szkolnym, a w konsekwencji - szansę na porównanie $\mathrm{z}$ rzeczywistością koncepcji teoretycznych omawianych $\mathrm{w}$ trakcie studiów. Co więcej, praktyki pozwalają uaktualnić własne plany działania na płaszczyźnie dydaktycznej, wychowawczej i opiekuńczej. Podczas praktyk przyszły nauczyciel zobowiązany jest do prowadzenia dokumentacji, w której zamieszcza własne scenariusze lekcji oraz krytyczne komentarze do prowadzonych przez nauczycieli zajęć. Ponadto ma możliwość dyskutowania z opiekunem praktyk i innymi nauczycielami. To sprawia, że wzbogaca swój warsztat w zakresie dydaktyczno-wychowawczym (Sobieszczyk, Wojciechowska, 2015, s. 51-54).

Potrzebę ustalenia priorytetów w kształceniu ustawicznym nauczycieli, wynikającą między innymi z obaw współczesnych pedeutologów o słabą jakość kształcenia i dokształcania nauczycieli, uwydatniają wymogi reformy edukacyjnej (wprowadzonej od 01.092000 r.). Dotyczą one przygotowania kadry do tworzenia własnych programów edukacyjnych i wychowawczych oraz dokonywania wyboru spośród proponowanych ofert programowych, ewaluacji programów edukacyjnych i wychowawczych, nauczania zintegrowanego, blokowego i realizacji ścieżek edukacyjnych, wprowadzenia wewnątrzszkolnych i zewnętrznych systemów oceniania, zarządzania placówką oświatową oraz kształcenia informatycznego i językowego (Szempruch, 2001, s. 153). 


\section{Zakończenie}

Całożyciowe kształcenie jest pojęciem szerokim, odnoszącym się do nabywania kompetencji, umiejętności, które mają służyć lepszemu dostosowaniu się do przemian społecznych, gospodarczych, politycznych, a także wspomagać samorozwój. Ma ono wiele elementów wspólnych z mistrzostwem pedagogicznym, które oznacza profesjonalizm w zawodzie nauczyciela. Bez całożyciowego kształcenia, a więc podejmowania różnych działań zmierzających do poznania świata i własnej osoby, poszerzania wiedzy i kompetencji, niemożliwe jest osiągnięcie profesjonalizmu przez nauczyciela, który dla ucznia ma być autorytetem, wzorem do naśladowania, a zarazem specjalistą w swojej dziedzinie. Całożyciowe kształcenie determinuje mistrzostwo pedagogiczne, a zarazem rozwój nauczyciela jest jednym $z$ elementów składowych całożyciowego kształcenia.

\section{Bibliografia}

Aleksander, T. (2009). Andragogika. Podręcznik akademicki, Radom-Kraków: Wydawnictwo Naukowe Instytutu Technologii Eksploatacji.

Carleo, A. (2013), Edukacja całożyciowa na przykładzie myśli pedagogicznej Don Lorenza Milaniego. „Polish Journal of Continuing Education”, nr 3, s. 19-26.

COM 678 (2001). Making a European Area of lifelong learning a reality. Communication from the Commission, 21 November.

Dróżka, W., Madalińska-Michalak, J. (2016). Droga do zawodu nauczyciela i motywy jej wyboru w świetle autobiograficznych wypowiedzi studentów studiów pedagogicznych. „Forum Oświatowe”, nr 28 (1), s. 161-179.

Konfucjusz (2008). Dialogi/Lun Yū. Cz. 1. Warszawa: Hachette Livre.

Kwiatkowski, S. M. (2018). Edukacja formalna, pozaformalna i nieformalna — wzajemne zwiazki. W: B. Śliwerski, M. Czerepaniak-Walczak, J. Madalińska-Michalak (red.), Ku życiu wartościowemu. Idee - koncepcje - praktyki. T. 1: Idee — koncepcje. Kraków: Impuls, s. 75-90.

Maniak, G. (2015). Kształcenie przez całe życie — idea i realizacja. Polska na tle Unii Europejskiej. „Zeszyty Naukowe Uniwersytetu Ekonomicznego w Katowicach”, 214, s. 128-139.

Marcinkiewicz, A. (2013). Pozaformalne i nieformalne aspekty edukacji akademickiej. „Ogrody Nauk i Sztuk", nr 3, s. 46-53.

Okoń, W. (2001). Nowy słownik pedagogiczny. Warszawa: Żak.

Pietrasiński, Z. (1990). Rozwój człowieka dorosłego. Warszawa: Wiedza Powszechna.

Poliwka-Gorczyńska, A. (2013). Ksztatcenie ustawiczne nauczycieli. Potrzeba czy konieczność? „Studia Dydaktyczne", 24-25, s. 81-93.

Półturzycki, J., (2005), Aktualność problemów edukacji ustawicznej. „Chowanna”, nr 2, s. 16-38.

Sobieszczyk, M., Wojciechowska, K. (2015). Praktyki pedagogiczne droga do mistrzostwa w zawodzie nauczyciela. „Przegląd Pedagogiczny”, nr 1, s. 51-60.

Szempruch, J. (2001). Nauczyciel w zmieniającej się szkole. Funkcjonowanie i rozwój zawodowy. Rzeszów: Wyd. Oświatowe FOSZE.

Szymański, M. J., Łukasik, J. M, Nowosad, I. (red.). (2014). Codzienność szkoły - nauczyciel. Kraków: Impuls.

Wiatrowski, Z. (2005). Podstawy pedagogiki pracy. Bydgoszcz: Akademia Bydgoska im. Kazimierza Wielkiego. 